\title{
The impact of short-selling on market efficiency and liquidity: Evidence from the emerging market of Egypt
}

\author{
Prepared 6y \\ Mennah Mortada Mahfouz \\ Nesma Ahmed EIShayeb \\ Lecturer of Accounting, Faculty of \\ Commerce, Cairo University \\ Lecturer of Accounting, Faculty of \\ Commerce, Cairo University \\ menna Mortada Mahfouz@foc.cu.edu.eg nesma ahmed elshayeb@foc.cu.edu.eg
}

Scientific Journal for Financial and Commercial Studies and Researches (SIFCSR)

Faculty of Commerce - Damietta University

Vol.3, No.1, Part 1., January 2022

APA Citation:

Mahfouz, M. M. and EIShayeb, N.A. (2022). The impact of short-selling on market efficiency and liquidity: Evidence from the emerging market of Egypt, Scientific Journal for Financial and Commercial Studies and Research, Faculty of Commerce, Damietta University, 3(1)1, pp. 113-151

Website: https://cfdj.journals.ekb.eg/ 
Scientific Journal for Financial and Commercial Studies and Researches

(SJFCSR) Faculty of Commerce - Damietta University

\title{
The impact of short-selling on market efficiency and liquidity: Evidence from the emerging market of Egypt
}

\author{
Mennah Mortada Mahfouz
}

Nesma Ahmed ElShayeb

\begin{abstract}
The purpose of this study is discussing the recent initiative to activate the short-selling mechanism in Egypt, through the issuance of the regulatory decision no. (268) of 2019 on short-selling. Besides, investigating its effect on market efficiency and liquidity according to market participants' perceptions. A questionnaire was formulated to explore the perceptions of academics, financial analysts, and brokers regarding the possible effects of the activation of short-selling mechanism on market efficiency and liquidity. Data were analyzed using descriptive statistics and multiple regression. Results of analyzing the 117 received questionnaires show that short-selling would not improve market efficiency, measured through price discovery and informativeness. However, there is a significant positive relationship between short-selling and financial reporting quality. Moreover, responses show a significant positive relationship between short-selling and market liquidity measured through; trading activity and volume, bid and ask spread, turnover ratio, and reduced market volatility. These findings support the assumption that short-selling could act as a mechanism to improve liquidity even in emerging markets. This study would benefit policymakers, in Egypt and any other countries with similar contexts, and foreign investment decisions. As it is important to investigate the opinion of parties who would be affected by lifting the restrictions on short-selling.
\end{abstract}

Keywords: Short-selling, Market Efficiency, Liquidity, Egyptian stock exchange market. 
Mennah Mortada Mahfouz \& Nesma Ahmed ElShayeb

\section{Introduction and background}

Over the last decade, the Egyptian stock market has witnessed significant changes in the trading environment, regulatory framework, political environment, and economic conditions. To cope with these changes, the Egyptian stock market regulatory agencies agreed to issue a short-selling mechanism on $26^{\text {th }}$ February 2019 as an attempt to improve the performance of the Egyptian stock market. However, it is still unclear whether the short-selling regulations could have the same impact on the less advanced, small, and thin markets, particularly in Egypt, as advanced, large, and deep markets.

A short sale is "a transaction in which short-sellers borrow securities to sell in anticipation of a price decline and return an equal number of the borrowed shares in the future" (Jiang and Chen, 2019). The short seller borrows the security from a securities lender, such as pension funds or insurance companies, either directly or through an intermediary (Geracia, et al., 2018). The goal is to benefit from a share price decline if the short position declines as anticipated. Thus, shortsellers are pessimistic about the future returns of a company's stock (Gehy, 2013). The two mechanisms for short-selling are covered and uncovered short sales. The covered short sale where the seller borrows the security then sells it short. On the other hand, the uncovered "naked" short sale does not require borrowing the stock beforehand. This could lead to a failure to deliver the security at the time of settlement (Geracia, et al., 2018).

There are various motives to borrow and short sell a stock; namely: purely directional short-selling, various arbitrage trading strategies, and reduction on tax on dividends payment that vary from country to country (Geracia, et al., 2018). Another line of studies considers the short-selling mechanism as a consequence of poor firms' performance, low reporting quality, and the need to improve liquidity. Chen et al., (2019) stated that it can reasonably be anticipated that firms with 'flaws' in their financial reporting information face a higher risk of being sold short. Moreover, Dechow et al. (2001) found that poor performance firms are subject to short-selling that reveals negative information. Additionally, short-selling is also affected by account information quality. Moreover, it was found 
Scientific Journal for Financial and Commercial Studies and Researches (SJFCSR) Faculty of Commerce - Damietta University

that short-selling increases before restatements, whereas stock price decreases after restatement (Desai et al., 2006). Short-selling can also arise from market-making and hedging. The former would provide liquidity to the markets, whereas the latter would allow users to manage risk more effectively (Lou, 2007; Deshmukh et al. 2015).

Short-selling has long been a controversial trading strategy. The academic evidence on the value of short-selling is contradictory. Many financial economists, market participants, and international organizations believe that short-selling might reduce volatility and contribute to market liquidity, thereby enhance overall market efficiency. Others, however, view short-selling as a key factor that contributes to exacerbating market volatility and stock market instability. This study explores how the Egyptian stock market participants perceive the impact of introducing the short-selling mechanism on market efficiency and market liquidity. This impact is considered in the Egyptian stock market as it is classified as a less advanced and emerging one. Furthermore, it provides insights into the country-level effect that are useful for policy-making and foreign investment decisions.

Based on the perceived benefits as well as limitations of shortselling, there is a debate regarding the degree of its restriction. Although most financial regulators agree that short-sellers play an important role to ensure that the market functions efficiently, many of them banned shortselling during the financial crisis (McKenzie and Henry, 2012). For example, in Europe, short-sellers were blamed for the debt crisis, due to usual suspects for financial turmoil and price decline. Consequently, European regulators restricted short-selling activities in 2008 (Bernal et al. 2014). Moreover, some market regulators, especially in less developed markets tend to impose short-selling restrictions to ban short-selling (Jain et al., 2013; Mertzanis, 2017).

Moreover, Jones and Lamont (2002) highlighted potential factors that might contribute to short-selling constraints. First, searching for stock lenders might be costly and time-consuming, especially, in noncentralized shorting markets. Second, stock loans are usually not term loans; this would increase the recall or buy-in risk. Besides, short-selling practices are banned in some countries; due to the illegal and abusive short-selling practices; specifically, bear raids and rumor-mongering that 
Mennah Mortada Mahfouz \& Nesma Ahmed ElShayeb

aim to reduce the stock price; as they would affect market stability (Jiang and Chen, 2019). Accordingly, policymakers started revising policies that would affect short-sellers' trading; to promote market efficiency and ensure that firms would be able to raise capital without price manipulation (Gehy, 2013). However, in countries with fewer regulations, short-sellers together with other market participants, such as institutional shareholders and financial analysts, are considered an additional mechanism to discipline managerial behavior (Jiang and Chen, 2019).

Short-selling regulations differ among countries; being developed or developing according to the market type or size. Chen et al., (2016) highlighted that the difference between the USA and China in the timing of short-selling and margin trading is due to differences in information disclosure regulations. China began to allow stocks to be sold short or bought on margin in 2010 through a list of designated securities, unlike the USA (Chen et al., 2019), where the short sale was banned in 2008 following the subprime crisis; to restore equilibrium to markets. Other European countries banned short-selling in 2011 namely: France, Belgium, Italy, and Spain. However, the stabilization through the short sale constraint is highly controversial (Chang et al., 2014). Ebrahimnejad and Hoseinzade (2019) found that firm-specific information might not be reflected in prices, resulting in higher stock price synchronicity in less developed markets, hence, most emerging markets constrain shortselling. However, removing these constraints would improve price efficiency and reduce the co-movement in prices. Emerging markets could benefit from short-selling by imposing regulations to ensure full and fair disclosure and prevent unlawful insider trading (Chen et al., 2016).

\section{Short-selling in Egypt}

Since the establishment of the Egyptian Stock Exchange Market, short-selling was banned. However, with the market growth, new financial instruments were needed to improve market efficiency and liquidity. On February 26, 2019, Dr. Mohammed Omran the Chairman of the Financial Regulatory Authority (FRA) issued a regulatory decision no. (268) of 2019 on short-selling rules and activating the mechanism, in which a list of designated securities can be sold short. The decision 
Scientific Journal for Financial and Commercial Studies and Researches

(SJFCSR) Faculty of Commerce - Damietta University

indicated that: "the Egyptian Stock Exchange, Misr for Central Clearing, Depository and Registry (MCDR) shall prepare and set up the automated systems and technical requirements related to short-selling mechanism".

Brokerage companies would have an important role in managing the short-selling system. Besides, they should provide the market with borrowers and lenders and check cash collateral. In addition, the selling proceeds and cash collateral should be reinvested in fixed instruments such as bank deposits, certificates of deposits, treasury bills. Moreover, custodians should enter contracts with clients wishing to short sale their securities where commissions are taken from them. On the other hand, MCDR should ensure that each lender ratio should not exceed $5 \%$ of the company's total shares and that each security lending ratio should amount to $20 \%$ of the listed shares. The lender maintains the rights and proceeds related to the ownership of the securities.

Based on EGX Chairman Decree No.757 for the year 2019 concerning the criterion of securities eligible for short-selling, the first list was issued in May 2019 with 30 stocks. It was also indicated that it will be updated periodically alongside both lists of securities allowed for specialized activities. During November, this list was updated to include 26 stocks eligible for short-selling transactions starting from December 2019. Fifty-one brokerage companies out of one hundred twenty-eight were licensed to offer short-selling in the Egyptian stock market till 2019. However, only ten big brokerage companies already have the technological system to conduct short-selling transactions.

\section{Research Contribution}

The contribution of this research is threefold. First, it addresses a recent initiative to activate the short-selling mechanism through the issuance of the regulatory decision no. (268) of 2019 on short-selling rules in Egypt. We think it is important to know the perceptions of market participants regarding this decision. Second, it investigates the opinion of specialists who would be affected by this decision, which in turn, would benefit policymakers in taking further actions or modifying existing regulations. We tried to present opinions of different specialists including academics, financial analysts, and brokers. Third, it addresses the Egyptian market; where results of an emerging market would add 
Mennah Mortada Mahfouz \& Nesma Ahmed ElShayeb

more insights as prior studies focused on the effect of short-selling after some years of its activation or restriction. Moreover, the results of this study might provide additional insights to other emerging markets with similar contexts to enhance the activation of short-selling mechanism in similar developing countries.

\section{Literature Review and hypotheses development}

Although prior studies investigated the effect of short-selling on stock markets' price discovery, efficiency, liquidity, and market stability, there is still a debate regarding these variables. Theoretical studies focused on one stock market and the results varied with the variations of different investors' assumptions in different markets. Furthermore, there are some limitations of empirical studies, such as the confidentiality of short-selling data in most countries and the variation of short-selling mechanisms and constraints. Therefore, most empirical studies tested short-selling through different approaches, which resulted in different conclusions (Gao and Gao, 2015). Recently, the real or perceived effects of short-selling grasped the attention of regulators as well as market participants such as issuers and investors. Short-selling provides benefits to some markets while negatively affects others. Various studies discussed the benefits of short-selling; the most important of which are price discovery, market efficiency, improving liquidity, and informative short-sellers.

\subsection{Short-selling and market efficiency}

Prior literature suggests that short-selling, as a correction tool, contributes to stock market efficiency through correcting stocks mispricing. Based on Miller's (1977) work, it is anticipated that the constraints of short-selling would result in stocks' overpricing. This prediction stems from the argument that with the absence of a shortseller, due to restriction, stock prices will reveal only the opinion of optimistic investors and oversight negative information, resulting in stocks over-valuation. With the absence of short-selling, pessimistic investors would not participate in the market, thus, prices would not reflect negative information, enabling enthusiastic buyers to bid prices above the fair prices (Mertzanis, 2017). Similarly, Diamond and Verrecchia (1987) indicated that the presence of short-selling constraints 
Scientific Journal for Financial and Commercial Studies and Researches

(SJFCSR) Faculty of Commerce - Damietta University

slows down prices' adjustments to private information, especially to bad news. Despite that, there is still a controversy regarding the impact of short-selling on market efficiency and it has been widely debated, especially, after the financial crisis.

Regulators, governments, and media support the assumption that short-sellers could lead to market declines. In contrast, financial economists have a different view arguing that short-selling leads to market efficiency (Sobaci et al., 2014). Various previous studies' results support the market efficiency assumption. Lou (2007) documented that short-sellers could help expose financial misrepresentation and other investors can potentially benefit from short seller's actions. Diether et al. (2009) results indicated that short-term stock prices' overreactions could be corrected by short-sellers after examining the daily short-selling activity of US stocks during 2005. Sobaci (2014) indicated that shortselling could correct mispricing, thereby, lead to efficient stock markets. Further, Beber and Pagano (2013) confirmed that the ban on short-selling would slow down price discovery. Bansal et al. (2013) also indicated that short-sale constraints reduce negative information incorporation in stock prices. In addition, restrictions on short-selling compromise the ability of the market to efficiently incorporate bad news in asset prices, resulting in an upward price bias (Jones and Lamont, 2002; Chang et al., 2007).

Similarly, previous studies suggested that the removal of shortselling restrictions would accelerate the incorporation of negative information into stock prices, and, in turn, increase price efficiency (Bris et al., 2007; Saffi and Sigurdsson, 2011; Boehmer and Wu, 2013). Accordingly, removing short-selling constraints would be considered a mechanism to enhance the overall market efficiency and liquidity. Chang et al. (2014) found that lifting the ban on short-selling would increase price efficiency and decrease stock return volatility. Further, Chen et al. (2016) conclude that stock prices' information efficiency has a positive association with short-selling intensity. Jiang and Pang (2016) found that short-selling improves investment decisions through increasing stock price informativeness. Jin et al. (2018) indicated that short-selling facilitates the flow of unfavorable news into stock prices that would improve stock price discovery and information efficiency. Moreover, short-selling could predict security price's poor performance (Chang et 
Mennah Mortada Mahfouz \& Nesma Ahmed ElShayeb

al., 2019). Accordingly, various studies support that short-selling would result in more efficient price discovery (Bris et al., 2007; Chang et al., 2007; McKenzie and Henry 2012; Boehmer and Wu, 2013).

Jin et al. (2018) indicated that short-selling affects corporate financial decisions positively. Besides, it increases accounting conservatism in short-selling Chinese firms. Karpoff and Lou (2010) found that short-sellers could identify, discover, and mitigate the effects of any financial misconduct. Furthermore, short-selling would enhance conservative accounting, as managers are required to identify and disclose bad news in financial reports (Jin et al., 2018). Therefore, shortsellers trading behaviors imply information signals to less-informed investors (Hu and $\mathrm{Chi}, 2019)$. Lepone et al. (2019) studied the impact of short-selling restrictions on futures mispricing in the market. It was found that short-selling restrictions result in more persistent futures underpricing in the market. Similar to the scope of the current research, Ebrahimnejad and Hoseinzade (2019) examined the effect of shortselling on stock price using a designated list of companies to be sold short in Hong Kong. They found that after the removal of short-selling constraints, the informativeness of stock prices increase.

Another stream of studies adopts the assumption that short-selling mechanism could negatively affect market efficiency. Uninformed and manipulative short-sellers might create fear among investors in a down market and cause market over-reactions, particularly to the negative corporate news event. Critics of short-selling argue that short-sellers manipulate share prices to pursue profits (Deshmukh et al., 2015). Shortsellers have received negative media attention and have been blamed for manipulating share prices downward and contributing to the financial crisis (Gehy, 2013). M Weiner et al. (2004) indicated that when stock prices of thinly capitalized issuers decline, often, the blame is on the short-seller. Moreover, other market participants have a concern regarding short sales conduct and view it as disruptive or manipulative. Supporting the stabilization function played by the short-sale constraint, Bris et al. (2007) found that stock returns are less negatively skewed in countries where short-selling is either not allowed or not practiced.

Lou (2007) revealed that there is an argument that companies targeted by short-selling activity often accuse short-sellers of 
Scientific Journal for Financial and Commercial Studies and Researches

(SJFCSR) Faculty of Commerce - Damietta University

manipulation by spreading negative information about that companies. Similary, Desai et al. (2006) and Christophe et al. (2010) found that short-sellers would exploit private information on upcoming negative corporate news before information announcements. Besides, Bernal et al. (2014) concluded that all short sale regulations harm market efficiency. Baklaci et al. (2016) found that trading activities by short-seller cause volatility of price changes, hence, destabilize the stock market. More recently, Engelberg et al., (2018) demonstrated that short-sellers are subject to various risks, as the risk that stock loans become expensive or recalled. Hence, stocks with more short-selling risk have lower returns, less price efficiency, and less short-selling.

According to the above discussion of the literature, the impact of short-selling on market efficiency provides inconsistent results from a different context. Some prior studies support the positive impact of shortselling on market efficiency through correcting any price overreactions, exposing financial misrepresentation, increasing accounting conservatism, increasing stock price informativeness. In contrast, other prior studies argued that the short-selling mechanism negatively affects market efficiency through manipulating share prices to pursue profits or increasing market volatility of the market. Accordingly, it can be expected that the activation of short-selling in the Egyptian stock exchange market might affect the market efficiency; therefore, the following null hypothesis is formulated:

H01: The activation of the short-selling mechanism in Egypt would not affect the market efficiency.

This hypothesis will be tested through the following sub hypotheses:

H01A: The activation of the short-selling mechanism in Egypt would not affect the price discovery.

H01B: The activation of the short-selling mechanism in Egypt would not affect the financial reporting quality.

H01C: The activation of the short-selling mechanism in Egypt would not affect the informativeness of the market. 
Mennah Mortada Mahfouz \& Nesma Ahmed ElShayeb

\subsection{Short-selling and liquidity}

Many prior studies were concerned with how short-sellers might contribute to the provision of liquidity. For example, Blau and Whitby (2018) indicated that regulators believe that short-selling is an important part of liquidity provision. Moreover, Diether et al. (2009) viewed that some liquidity providers might be willing to short stocks; to provide liquidity during bullish periods. Furthermore, Blau and Whitby (2018) concluded that the presence of short-sellers, being informed traders, the market makers would widen bid-ask spreads. Similarly, Sobaci et al. (2014) found that increased short-selling was associated with higher liquidity and less volatility, thus improving market quality in Turkey, in the whole sample period; including the financial crisis in 2008.

Supporting this view, some studies highlighted that the ban or constraints of short-selling would be unfavorable to the market liquidity. Lensberg et al. (2015) indicated that when more than 30 countries banned short-selling in 2008, financial practitioners, in contrast to policymakers, claimed that these regulations would reduce liquidity and increase the cost of capital. Moreover, Boehmer et al. (2013) found that although the USA ban in 2008 was intended to stabilize the capital markets, it resulted in reduced liquidity, slow price discovery, and reduced market quality. Alves et al. (2016) also found that short-selling bans negatively affect liquidity after their implementation. Moreover, other studies claimed that constraints on short-selling would result in reduced liquidity and higher volatility, which, in turn, would negatively affect the market quality (Sobaci, et al., 2014). Beber and Pagano (2013) indicated that imposing bans or regulatory constraints during the crisis (2007-2009) was unfavorable to market liquidity, especially for stocks with small market capitalization. Besides, Jin et al. (2018) indicated that regulators in some emerging markets ban short-selling; as it is considered risky and would increase market volatility while undermining market confidence due to the presence of informed, short-sellers, and uninformed traders.

Although the above-mentioned studies highlighted the positive effect of short-selling on market liquidity, other studies suggested that short-selling negatively affects liquidity. For example, Karpoff and Lou (2010) claimed that short-sellers decrease market liquidity as they 
Scientific Journal for Financial and Commercial Studies and Researches

(SJFCSR) Faculty of Commerce - Damietta University

undermine investors' confidence in the market. Moreover, Jin et al. (2018) regarded that as short-selling increase market volatility and undermine investors' confidence, it could be considered risky. Furthermore, Sharif et al. (2014) concluded that the trading volume would decline when less informed and uninformed investors avoid trading against better-informed short-sellers. Finally, Brunnermeier and Pedersen (2005) indicated that predatory traders might front-run shortsellers, attempting to liquidate their positions, resulting in less liquidity.

To sum up, studies that supported the relationship between shortselling and market liquidity showed contradictory results. Whereas some studies concluded that short-selling would increase liquidity by affecting its measures, such as trading activity, trading volume, bid and ask, turnover ratio and reduced volatility, another stream of studies supported the opposite view. Results would vary according to the choice of data and methodology used for the analysis and the microstructure setting in which the analysis is carried out (Mertzanis, 2017).

On the other hand, Mertzanis (2017) claimed that there is no relationship between short-selling and market liquidity. It was found that although short-selling would result in more volatile aggregate stock returns in the short run, it does not significantly affect the market. Finally, the study indicated that the effect of short-selling on market volatility and liquidity needs further investigation, where considering the institutional firm-level and country-level elements would provide a more comprehensive understanding. Based on the different results of prior studies, the following hypothesis is formulated to test the relationship, if any, between short-selling and market liquidity within the Egyptian context.

H02: The activation of the short-selling mechanism in Egypt would not affect the market liquidity.

This hypothesis will be tested through the following sub hypotheses:

H02A: The activation of the short-selling mechanism in Egypt would not affect the trading activity and volume.

H02B: The activation of the short-selling mechanism in Egypt would not affect the bid and ask, turnover ratio, and volatility. 
Mennah Mortada Mahfouz \& Nesma Ahmed ElShayeb

\section{Data collection}

Data was gathered through a questionnaire to determine respondents' perception regarding the activation of short-selling in Egypt and its effect on efficiency and liquidity. It included a cover page indicating the main purpose and assuring confidentiality besides illustrating the used concepts. It was divided into 3 sections: personal information, 30 questions, and other comments. A Likert scale was used: completely agree, agree, neutral, disagree, or completely disagree. These categorical data were then converted into numeric data for regression analysis; from 1 (completely disagree) to 5 (completely agree).

Questions were then divided into 5 groups, the first one (3 questions) considered the difference between Egypt and developed countries, the benefit for the Egyptian stock market, and restrictions in case of market instability. The second one (4 questions) aimed to measure the independent variable, short-selling: timing, number of stocks, market participants' encouragement, and capabilities to effectively use it. The third group measured the dependent variables; efficiency was measured through price discovery (4 questions), financial reporting quality (3 questions), and informativeness (5 questions). Besides, liquidity was measured through trading volume and activity (4 questions), bid and ask, turnover ratio, and volatility (3 questions). The fourth group (2 questions) measured the control variables: industry type and company size. Finally, the last group ( 2 questions) aimed to validate the answers of the dependent variables. These measures were selected based on the literature used empirical measures then it is converted into questions to reflect each variable.

\subsection{Population and sample size}

The population of this study is experts in the Egyptian stock market as the questionnaire aims to explore their opinions regarding the activation of short-selling in Egypt. Accordingly, the researchers regarded both the academics -with accounting or finance majors, as well as practitioners, including financial analysts and brokers. Besides, academic staff in universities are targeted as being knowledgeable about the field and the newly issued regulations. This choice is mainly to consider the difference in opinions between academia and market 
Scientific Journal for Financial and Commercial Studies and Researches

(SJFCSR) Faculty of Commerce - Damietta University

practitioners. The researchers focused on academics in Egyptian Universities. As for practitioners, the target group was financial analysts and brokers working in the Egyptian market, whether in brokerage companies, private institutions, banks, or the Egyptian stock market.

The researchers could not identify the specific number of total populations; as there is no census for the financial analysts, brokers and academics specialized in accounting and finance. Accordingly, the sample size was determined based on the number of questions; the questionnaire had 30 main questions. Given that the acceptable sample size would have 10 observations per variable (10:1) (Hair et al., 2010), the sample size was 300 . The researchers distributed the questionnaires to the target group, through an online copy using "Google form". This comprises both Arabic and English versions of the questionnaire.

First, the questionnaire was sent via email to all brokerage firms in Egypt. Besides, individual messages were sent to financial analysts and brokers through LinkedIn. The recipients were selected randomly, taking into consideration the weight of the three categories: academics, financial analysts, and brokers. As for academics, the researchers contacted them personally through private messages. Responses were gathered during three months, where we received 17 Arabic responses and 100 English responses. The response rate was $39 \%$, which was considered acceptable as the number of responses exceeded the minimum number of observations required to run SPSS is 30 .

\section{Data analysis}

Data were analyzed using SPSS (26); both descriptive (frequencies and cross-tabulation), as well as statistical analyses (Cronbach's Alpha, and multiple regression), were used. The former was used for the first section of the questionnaire, as well as the first and last groups of questions. The latter was used for the second, third, and fourth groups of questions.

\subsection{Descriptive analysis}

\subsubsection{Sample description}

The researchers received 117 complete questionnaires from financial analysts $(34.2 \%)$, academic staff $(30.8 \%)$, brokers $(14.5 \%)$, and 
Mennah Mortada Mahfouz \& Nesma Ahmed ElShayeb

others (20.5\%). Other respondents included: bankers, administrators, credit analysts, accountants, financial managers, investment managers, financial consultants, technical analysts, investors. The researchers regard the variation between academics and practitioners (financial analysts and brokers) as informative as different perceptions are considered. Most respondents are specialized in finance $(60.7 \%)$, compared to $24.8 \%$ in accounting. The other $14.5 \%$ were specialized in marketing, administration, credit, banking, economic sciences, and law. This was due to they are more familiar with the topic and had some experience with short-selling, more than the other specializations. As for the years of experience, it was approximately equally distributed among "less than 5 years: (35\%), "from 5 to 10 years" $(26.5 \%)$, and "above 10 years" $(38.5 \%)$. The researchers regard this distribution as reliable as different opinions from different generations were considered.

\subsubsection{Frequencies and cross-tabulation}

The following tables $(1 \&$ \& $)$ summarize the results of the descriptive statistics for the first group of questions; including measures of central tendency (mean, median, and mode), as well as measures of variability (standard deviation). Besides, cross-tabulation was conducted to analyze the difference in responses between the 3 categories of the population; academics, financial analysts, and brokers; as well as the difference in opinions according to the years of experience; which ranged from less than 5 years, between 5 and 10 years and more than 10 years.

According to previous studies, short-selling mechanisms might differ from developing to developed countries. Question (6) investigated whether the consequences of short-selling in Egypt, as a developing country, would differ from developed countries. Results showed that on average, respondents agreed that the consequences of short-selling in Egypt would differ from developed countries (mean 3.83). Similarly, the median was also 4 "agree" and the mode was 4 ; indicating that most respondents agreed that there would be differences. Moreover, it also revealed a deviation of (1.077); This result is consistent with Jain et al. (2013), Chen et al. (2016), Mertzanis (2017), Ebrahimnejad and Hoseinzade (2019); which pointed variations between developing and developed countries; in the timing of short-selling activation or banning and its impact on stock prices. 
Scientific Journal for Financial and Commercial Studies and Researches

(SJFCSR) Faculty of Commerce - Damietta University

Cross tabulation indicated that there are differences between respondents according to their jobs. $75 \%$ of the academic staff agreed -or strongly agreed- that there would be a difference, whereas $63 \%$ of financial analysts had the same opinion, compared to $59 \%$ of brokers and $58 \%$ of "others". This variation might result from the gap between academics and practitioners. In other words, $75 \%$ of academics' views there would be a difference, where $60 \%$ of practitioners agree. As for the specialization, there were slight differences $(69 \%$ accounting specialization, $63 \%$ finance, and $64 \%$ other specialization). Results also varied according to the years of experience; respondents with the least experience (less than 5 years) agreed the most that there would be a difference $(76 \%)$, followed by $62 \%$ of the most experienced (more than 10 years) and only $55 \%$ of 5 to 10 years' experience. The researchers view that years of experience has a role in expressing their opinions that is subject to more experiences.

As short-selling is considered a new mechanism for the Egyptian market, question (9) investigates whether the Egyptian market would benefit from its activation nowadays. Results showed that on average, respondents agreed that there would be some benefits (mean 4.03). Similarly, the median was also 4 "agree" and the mode was 4 ; indicating that the most chosen opinion was "agree". Moreover, it also revealed a standard deviation of (0.973). These responses are consistent with the literature that short-selling provides various benefits, such as price discovery, efficiency, liquidity, and less volatility (Bris et al., 2007; McKenzie and Henry, 2012; Sobaci, et al., 2014; Chang et al., 2016; Jin et al., 2018). Further, this result is consistent with some comments of practitioners, who encouraged the introduction of short-selling.

Cross tabulation indicated that academics were more optimistic regarding the benefits from short-selling $(92 \%$ either agreed or completely agreed that there would be benefits compared to $70 \%$ of practitioners). Opinions of brokers, financial analysts, and others were quite similar $(71 \%, 68 \%$, and $75 \%$ respectively). Furthermore, there were fewer variations based on specialization $(86 \%$ of accounting specialization agreed, compared to $75 \%$ finance and $71 \%$ other specialization). Besides, those with less than 5 years of experience were the least pessimistic regarding the benefits that short-selling would render 
Mennah Mortada Mahfouz \& Nesma Ahmed ElShayeb

(66\%), compared to $81 \%$ of 5 to 10 years' experience and $84 \%$ of more than 10 years' experience.

In many countries, some restrictions are made on short-selling. Question (10) investigated whether restrictions of short-selling are preferred in case of market instability. Results, on average, were slightly above neutral towards imposing restrictions in case of market instability (mean 3.29). Similarly, the median was also 3 "neutral". However, the mode was 4; indicating that the most chosen opinion was "agree". Moreover, it also revealed a standard deviation of (1.333); which is a relatively high variation of responses compared with the other two questions (Q6 \& Q9). This result is inconsistent with Jain et al. (2013) and Mertzanis (2017) that noted the restriction of short-selling is used in less developed countries to increase stability. The researchers view that this might be because it is still relatively new in Egypt, so there is no clear conception regarding the appropriate time for restrictions.

Cross tabulation indicated high variation in opinions, regarding imposing restrictions in case of market instability, between academics (61\%) compared to practitioners (44\%). However, opinions of different categories of practitioners were similar $(47 \%$ brokers, $45 \%$ financial analysts, and $42 \%$ others). As for the first two questions, results did not vary a lot according to the specialization (48\% accounting, $51 \%$ finance, and $47 \%$ other). Finally, the years of experience affected the opinions (39\% of the least experienced, compared to $55 \%$ of the moderate experienced and $56 \%$ of the more experienced). 
Scientific Journal for Financial and Commercial Studies and Researches (SJFCSR) Faculty of Commerce - Damietta University

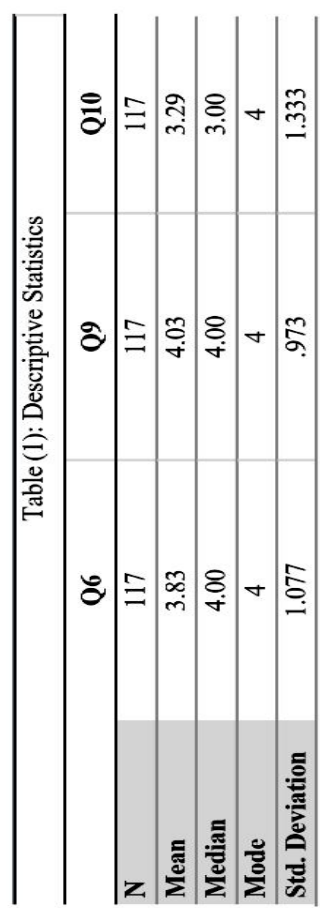

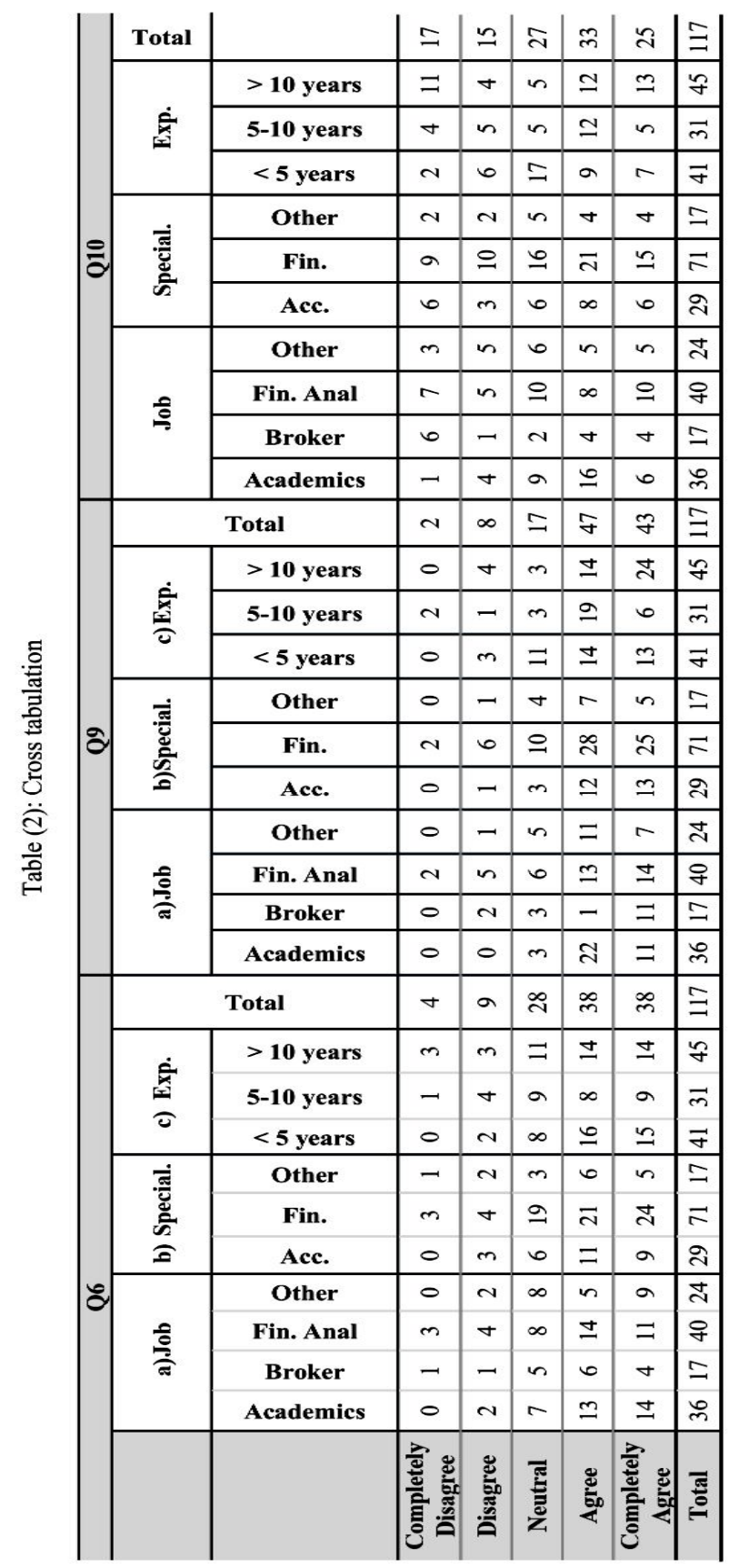


Mennah Mortada Mahfouz \& Nesma Ahmed ElShayeb

\subsubsection{Statistical Analysis}

\subsubsection{Reliability of the questionnaire}

Cronbach's Alpha was used to test the reliability of the used questionnaire. It was found that the overall reliability of the questions is (0.82) which is considered acceptable. The following table shows the reliability statistics for the whole questionnaire, as well as for each measure. As shown below, Cronbach's Alpha is greater than half for all measures, with close values, except for "market informativeness".

Table (3): Reliability statistics

\begin{tabular}{|l|c|c|}
\hline \multicolumn{1}{|c|}{ Variable } & $\begin{array}{c}\text { No. of } \\
\text { questions in } \\
\text { each variable }\end{array}$ & $\begin{array}{c}\text { Cronbach's } \\
\text { Alpha }\end{array}$ \\
\hline Short-selling & 4 & .579 \\
\hline Efficiency-Price discovery & 4 & .547 \\
\hline Efficiency- Financial reporting quality & 3 & .553 \\
\hline Efficiency- informativeness of the market & 5 & .355 \\
\hline Liquidity- Trading activity \& volume & 4 & .598 \\
\hline $\begin{array}{l}\text { Liquidity- Bid \& Ask, Turnover ratio and } \\
\text { Volatility }\end{array}$ & 3 & .603 \\
\hline Overall questionnaire & 30 & .818 \\
\hline
\end{tabular}

\subsubsection{Multiple Regression}

This section presents the results of the statistical analysis used to test the study's hypotheses. Regression was used to test the strength and direction of the relationship between short-selling and each of market efficiency and market liquidity. As indicated previously, market efficiency is tested through; price discovery, financial reporting quality, and informativeness. Market liquidity is tested through; trading activity and volume, bid and ask, and turnover ratio and volatility. Since the effect of short-selling on the market would vary according to industry type or company size (Chen et al., 2016; Jiang and Pang, 2016; Hu and Chi, 2019), they are included as control variables in the regression models. Furthermore, as various measures of liquidity are likely related 
Scientific Journal for Financial and Commercial Studies and Researches

(SJFCSR) Faculty of Commerce - Damietta University

to efficiency measures, liquidity measures are considered as control variables when measuring efficiency and vice versa.

\subsubsection{Testing the first hypothesis}

The first hypothesis assumes that short-selling would not affect market efficiency, through; price discovery, reporting quality, and informativeness. Multiple regression was used to test whether the activation of short-selling, as an independent variable, would affect each market efficiency measure independently and the efficiency compound variable, while controlling for the effect of size, industry type, and liquidity measures.

The first model tests whether the activation of short-selling in Egypt would affect price discovery, considering the above-mentioned controls. Regression results, table (4), show that $16 \%$ only of variation in efficiency-price discovery can be attributed to short-selling, industry type, size, and liquidity measures, which indicates that there are other economic and market factors beyond our analysis and focus that might affect it. Further, short-selling has an insignificant positive relationship with price discovery. This result is inconsistent with previous studies of Chang et al. (2007), McKenzie and Henry (2012), Sobaci et al. (2014), Chen et al. (2016), Mertzanis (2017), Jin et al. (2018). Hence, the first null sub-hypothesis is accepted; indicating that the activation of the short-selling mechanism would not affect price discovery. In addition, the firm size has a significant positive relationship with price discovery at 0.05 . This result is consistent with the argument in the literature that the positive impact of short-selling is more pronounced in large firms (Chen et al., 2016; Hu and Chi, 2019).

EFF.PRIC $=\mathbf{B}_{0}+\mathbf{B}_{1}$ SH + B $_{2}$ Ind + B $_{3}$ Size + B $_{4}$ Liq $_{1}+\mathbf{B}_{5}$

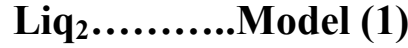

\section{Where:}

EFF.PRIC $=$ Efficiency measured by price discovery.

SH= Short-selling.

Ind= Industry type.

Size $=$ Size . 


\section{Mennah Mortada Mahfouz \& Nesma Ahmed EIShayeb}

$\mathbf{L i q}_{1}=$ Liquidity measured by trading activity and volume.

$\mathbf{L i q} \mathbf{q}_{2}=$ Liquidity measured by bid and ask, turnover ratio, and volatility.

The second model tests whether the activation of short-selling in Egypt would affect the financial reporting quality, considering the controls. Regression results, table (4), show that $27.8 \%$ of the variation in financial reporting quality can be attributed to variation in short-selling, industry type, size, and liquidity measures. Moreover, short-selling has a positive significant relationship with financial reporting quality, at a significance level of 0.05 . This result confirms the empirical literature that indicates that short-selling increases conservatism in financial reporting and exposes financial misrepresentation (Lou, 2007; Karpoff and Lou, 2010؛ Lou, 2010; Jin et al., 2018). Accordingly, the second null sub-hypothesis is rejected; indicating that the activation of the shortselling mechanism would positively affect financial reporting quality. Moreover, the size and the $\mathrm{Liq}_{2}$ have a significant positive relationship with reporting quality at 0.01 level.

$$
\begin{aligned}
& \text { EFF.REP }=B_{0}+B_{1} \text { SH }+ \text { B }_{2} \text { Ind }+ \text { B }_{3} \text { Size }+ \text { B }_{4} \text { Liq }_{1}+B_{5}
\end{aligned}
$$

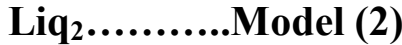

\section{Where:}

EFF.REP= Efficiency measured by financial reporting quality.

Other variables: same as in model (1). 
Scientific Journal for Financial and Commercial Studies and Researches (SJFCSR) Faculty of Commerce - Damietta University

Table (4): Regression results: Models 1 and 2

\begin{tabular}{|c|c|c|c|c|c|c|c|c|c|c|}
\hline & \multicolumn{5}{|c|}{ Panel A: Model (1) Summary } & \multicolumn{5}{|c|}{ Panel A: Model (2) Summary } \\
\hline & $R$ & $R^{2}$ & $\begin{array}{l}\text { Adjj. } \\
R^{2}\end{array}$ & $\begin{array}{c}\text { Std. } \\
\text { Error }\end{array}$ & $\begin{array}{c}\text { Sig. } \\
\text { F }\end{array}$ & $\boldsymbol{R}$ & $R^{2}$ & $\operatorname{Adj} . R^{2}$ & $\begin{array}{c}\text { Std. } \\
\text { Error }\end{array}$ & $\begin{array}{c}\text { Sig. } \\
F\end{array}$ \\
\hline & 0.401 & 0.161 & 0.123 & 2.705 & 0.001 & .527 & .278 & .245 & 1.899 & 0.000 \\
\hline & \multicolumn{5}{|c|}{ Panel B: Coefficients } & \multicolumn{5}{|c|}{ Panel B: Coefficients } \\
\hline \multirow{2}{*}{$\begin{array}{c}\text { Independent } \\
\text { variables }\end{array}$} & \multicolumn{2}{|c|}{$\frac{\text { Unstand. }}{\text { Coeff. }}$} & \multirow{2}{*}{$\frac{\frac{\text { Stand. }}{\text { Coeff. }}}{\text { Beta }}$} & \multirow[b]{2}{*}{$\begin{array}{c}t- \\
\text { value }\end{array}$} & \multirow[b]{2}{*}{ Sig. } & \multicolumn{2}{|c|}{$\frac{\text { Unstand. }}{\text { Coeff. }}$} & \multirow{2}{*}{$\frac{\frac{\text { Stand. }}{\text { Coeff. }}}{\text { Beta }}$} & & \\
\hline & B & $\begin{array}{c}\text { Std. } \\
\text { Error }\end{array}$ & & & & $B$ & $\begin{array}{c}\text { Std. } \\
\text { Error }\end{array}$ & & $\begin{array}{c}t- \\
\text { value }\end{array}$ & Sig. \\
\hline (Constant) & 6.440 & 1.945 & & $\begin{array}{l}3 . \\
311\end{array}$ & .001 & 4.119 & 1.366 & & 3.016 & .003 \\
\hline SH & .127 & .090 & .140 & 1.413 & .160 & .138 & .063 & .202 & 2.189 & .031 \\
\hline Ind & .226 & .232 & .091 & .976 & .331 & .148 & .163 & .078 & .907 & .367 \\
\hline Size & .554 & .277 & .192 & 1.998 & .048 & .546 & .195 & .251 & 2.806 & .006 \\
\hline $\operatorname{Liq}_{1}$ & .015 & .110 & .014 & .138 & .890 & -.018 & .078 & -.022 & -.231 & .818 \\
\hline $\mathbf{L i q}_{2}$ & .214 & .129 & .170 & 1.657 & .100 & .242 & .091 & .255 & 2.677 & .009 \\
\hline $\begin{array}{c}\text { Dependent } \\
\text { Variable }\end{array}$ & \multicolumn{5}{|c|}{ EFF.PRIC } & \multicolumn{5}{|c|}{ EFF. REP } \\
\hline
\end{tabular}

The third model tests whether the activation of short-selling in Egypt would affect the market informativeness, considering the controls. Regression results, table (5), show that only $13.9 \%$ of the variation in informativeness can be attributed to short-selling, industry type, size, and liquidity measures. Further, there is no significant relationship between short-selling and informativeness. Hence, the third null sub-hypothesis is accepted; indicating that the activation of short-selling would not affect informativeness. This is inconsistent with Engelberg et al. (2012), Chang et al. (2014), Jiang and Pang (2016), Blau and Whitby (2018). Besides, $\mathrm{Liq}_{1}$ has a significant positive relationship with informativeness at 0.01 level. This might be due to the assumed relation that liquidity might enhance efficiency and vice versa.

$$
\begin{gathered}
\text { EFF.INF }=\text { B }_{0}+\text { B }_{1} \text { SH }+ \text { B }_{2} \text { Ind }+ \text { B }_{3} \text { Size }+ \text { B }_{4} \text { Liq }_{1}+B_{5} \\
\text { Liq }_{2} \ldots \ldots \ldots \ldots . \text { Model (3) }
\end{gathered}
$$




\section{Mennah Mortada Mahfouz \& Nesma Ahmed EIShayeb}

Where:

EFF.INF $=$ Efficiency measured by informativeness.

Other variables: same as in model (1).

The fourth model tests whether the activation of short-selling in Egypt would affect the efficiency compound three measures, considering the controls. Results, table (5), show that the $27.3 \%$ of changes in total market efficiency, could be attributed to the activation of short-selling, industry type, size, and liquidity measures. Furthermore, there is no significant relationship between short-selling and efficiency compound measure. This is inconsistent with Chang et al. (2014), Chen et al., (2016), Jin et al. (2018), and Ebrahimnejad and Hoseinzade (2019). This might be attributed to investigating perceptions of the consequences of activating short-selling based on a questionnaire, while prior studies analyzed the effect of the presence of short-selling on market efficiency. Accordingly, the first main null hypothesis is accepted supporting that short-selling does not affect the compound market efficiency. However, the size and $\mathrm{Liq}_{2}$ show a significant positive relationship with compound market efficiency at 0.05 . These results support the assumption that liquidity is one of the main variables that enhance market efficiency. Moreover, short-selling within larger companies would affect efficiency.

$$
\begin{aligned}
& \text { EFF.COM. }=\text { B }_{0}+\text { B }_{1} \text { SH }+ \text { B }_{2} \text { Ind }+ \text { B }_{3} \text { Size }+ \text { B }_{4} \text { Liq }_{1}+B_{5} \\
& \text { Liq } 2 \text {...........Model (4) }
\end{aligned}
$$

\section{Where:}

EFF.COM= Efficiency measured by a compound measure of EFF.PRIC, EFF.REP, and EFF.INF

Other variables: same as in model (1). 
Scientific Journal for Financial and Commercial Studies and Researches (SJFCSR) Faculty of Commerce - Damietta University

Table (5): Regression results: models (3) and (4).

\begin{tabular}{|c|c|c|c|c|c|c|c|c|c|c|}
\hline & \multicolumn{5}{|c|}{ Panel A: Model (3) Summary } & \multicolumn{5}{|c|}{ Panel A: Model (4) Summary } \\
\hline & $R$ & $R^{2}$ & $\operatorname{Adj.} R^{2}$ & $\begin{array}{c}\text { Std. } \\
\text { Error }\end{array}$ & Sig. $F$ & $\boldsymbol{R}$ & $R^{2}$ & $\operatorname{Adj} . R^{2}$ & $\begin{array}{c}\text { Std. } \\
\text { Error }\end{array}$ & $\underset{F}{\text { Sig. }}$ \\
\hline & .372 & .139 & .100 & 2.574 & 0.005 & .522 & .273 & .240 & 5.145 & .000 \\
\hline & \multicolumn{5}{|c|}{ Panel B: Coefficients } & \multicolumn{5}{|c|}{ Panel B: Coefficients } \\
\hline \multirow{2}{*}{$\begin{array}{c}\text { Independent } \\
\text { variables }\end{array}$} & \multicolumn{2}{|c|}{$\frac{\text { Unstand. }}{\text { Coeff. }}$} & $\frac{\text { Stand. }}{\text { Coeff. }}$ & & & \multicolumn{2}{|c|}{$\underline{\text { Unstand.Coeff. }}$} & $\frac{\text { Stand. }}{\text { Coeff. }}$ & & \\
\hline & $B$ & $\begin{array}{c}\text { Std. } \\
\text { Error }\end{array}$ & Beta & $\begin{array}{c}t- \\
\text { value }\end{array}$ & Sig. & $B$ & $\begin{array}{c}\text { Std. } \\
\text { Error }\end{array}$ & Beta & $\begin{array}{c}t- \\
\text { value }\end{array}$ & Sig. \\
\hline (Constant) & 9.668 & 1.851 & & 5.224 & .000 & 20.227 & 3.699 & & 5.468 & .000 \\
\hline SH & -.020 & .085 & -.023 & -.230 & .819 & .245 & .170 & .133 & 1.436 & .154 \\
\hline Ind & .346 & .221 & .148 & 1.567 & .120 & .720 & .441 & .141 & 1.632 & .106 \\
\hline Size & .193 & .264 & .071 & .732 & .466 & 1.294 & .527 & .220 & 2.453 & .016 \\
\hline $\mathbf{L i q}_{1}$ & .283 & .105 & .281 & 2.696 & .008 & .281 & .210 & .128 & 1.336 & .184 \\
\hline $\mathrm{Liq}_{2}$ & .099 & .123 & .084 & .809 & .420 & .555 & .245 & .216 & 2.264 & .025 \\
\hline $\begin{array}{l}\text { Dependent } \\
\text { Variable }\end{array}$ & \multicolumn{5}{|c|}{ EFF. INF } & \multicolumn{5}{|c|}{ EFF. COM } \\
\hline
\end{tabular}

\subsubsection{Testing the second hypothesis}

Multiple regression was used to test whether the activation of shortselling would affect each liquidity measure independently as well as the compound measure while controlling for the effect of size, industry type, and the three efficiency measures.

The fifth model tests whether the activation of short-selling in Egypt would affect liquidity measured by the trading activity and volume, considering the controls. Results, table (6), show that $19.7 \%$ of the variation in trading activity and volume can be attributed to shortselling, industry type, size, and efficiency measures. Moreover, there is a significant positive relationship between short-selling and trading activity and volume, at a significance level of 0.01 . This is consistent with Chague et al. (2019) that short-selling increases trading volume, while inconsistent with Sharif et al. (2014) that short-selling decreases trading volume. Hence, the null hypothesis is rejected; indicating that the activation of short-selling would positively affect the trading activity and volume. Besides, informativeness, as a measure of efficiency, has a 
Mennah Mortada Mahfouz \& Nesma Ahmed ElShayeb

significant relationship with $\mathrm{Liq}_{1}$ at 0.01 , supporting that informed market participants might enhance the liquidity by increasing their trading volume.

\section{Liq $_{1}=B_{0}+B_{1} S H+B_{2}$ Ind $+B_{3}$ Size $+B_{4}$ EFF.PRIC $+B_{5}$ EFF.REP $+B_{6}$ EFF.INF Model(5)}

\section{Where:}

$\mathbf{L i q}_{1}=$ Liquidity measured by trading activity and volume.

Other variables: same as previous models.

The sixth model tests whether the activation of short-selling in Egypt would affect liquidity measured by bid and ask, turnover ratio, and volatility, considering the controls. Results, table (6), show that $19.3 \%$ of the variation in the bid and ask, turnover ratio, and volatility can be attributed to short-selling, industry type, size, and efficiency measures. Moreover, there is a significant positive relation between short-selling and $\mathrm{Liq}_{2}$, at a significance level of 0.05 . This is consistent with Sobaci et al. (2014) and Blau and Whitby (2018) that short-selling increases liquidity. Therefore, the null hypothesis is rejected; indicating that the activation of short-selling would affect the bid and ask, turnover ratio positively and decrease volatility. Further, the efficiency, measured by reporting quality, has a positive significant relationship with $\mathrm{Liq}_{2}$, at 0.05 . This indicates that respondents regard market liquidity could be improved through enhancing financial reporting quality.

\section{$\mathbf{L i q}_{2}=\mathbf{B}_{0}+$ B $_{1}$ SH + B $_{2}$ Ind + B $_{3}$ Size + B $_{4}$ EFF.PRIC $+B_{5}$ EFF.REP + $B_{6}$ EFF.INF..........................................Model (6)}

\section{Where:}

$\mathbf{L i q}_{2}=$ Liquidity measured by bid and ask, and turnover ratio and volatility.

Other variables: same as previous models.

The seventh model tests whether the activation of short-selling in Egypt would affect the compound measure of liquidity, considering the controls. Results, table (6), show that $23.3 \%$ of changes in market liquidity, measured by the compound measure of liquidity could be attributed to the activation of short-selling, industry type, size, and 
Scientific Journal for Financial and Commercial Studies and Researches

(SJFCSR) Faculty of Commerce - Damietta University

efficiency measures. Furthermore, the relation between short-selling and compound measure of liquidity is significant at 0.01 level. This result supports the assumption in prior literature that banning short-selling would decrease market liquidity (Sobaci, et al., 2014; Lensberg et al., 2015; Alves et al., 2016). Moreover, it confirms the sub-hypotheses results that the activation of short-selling affects all measures of market liquidity; hence, the second main null hypothesis is rejected. Moreover, informativeness, as a measure of efficiency, have a significant relationship with liquidity compound measure at 0.01 . Hence, informed market participants and the existence of short-selling might improve liquidity.

Liq.COM $=$ B $_{0}+B_{1}$ SH + B $_{2}$ Ind + B $_{3}$ Size + B $_{4}$ EFF.PRIC $+B_{5}$

EFF.REP + $B_{6}$ EFF.INF.........................Model (7)

\section{Where:}

Liq.COM = liquidity measured by a compound measure of $\mathrm{Liq}_{1}$ and $\mathrm{Liq}_{2}$.

All other variables: same as the model (1). 
Mennah Mortada Mahfouz \& Nesma Ahmed EIShayeb

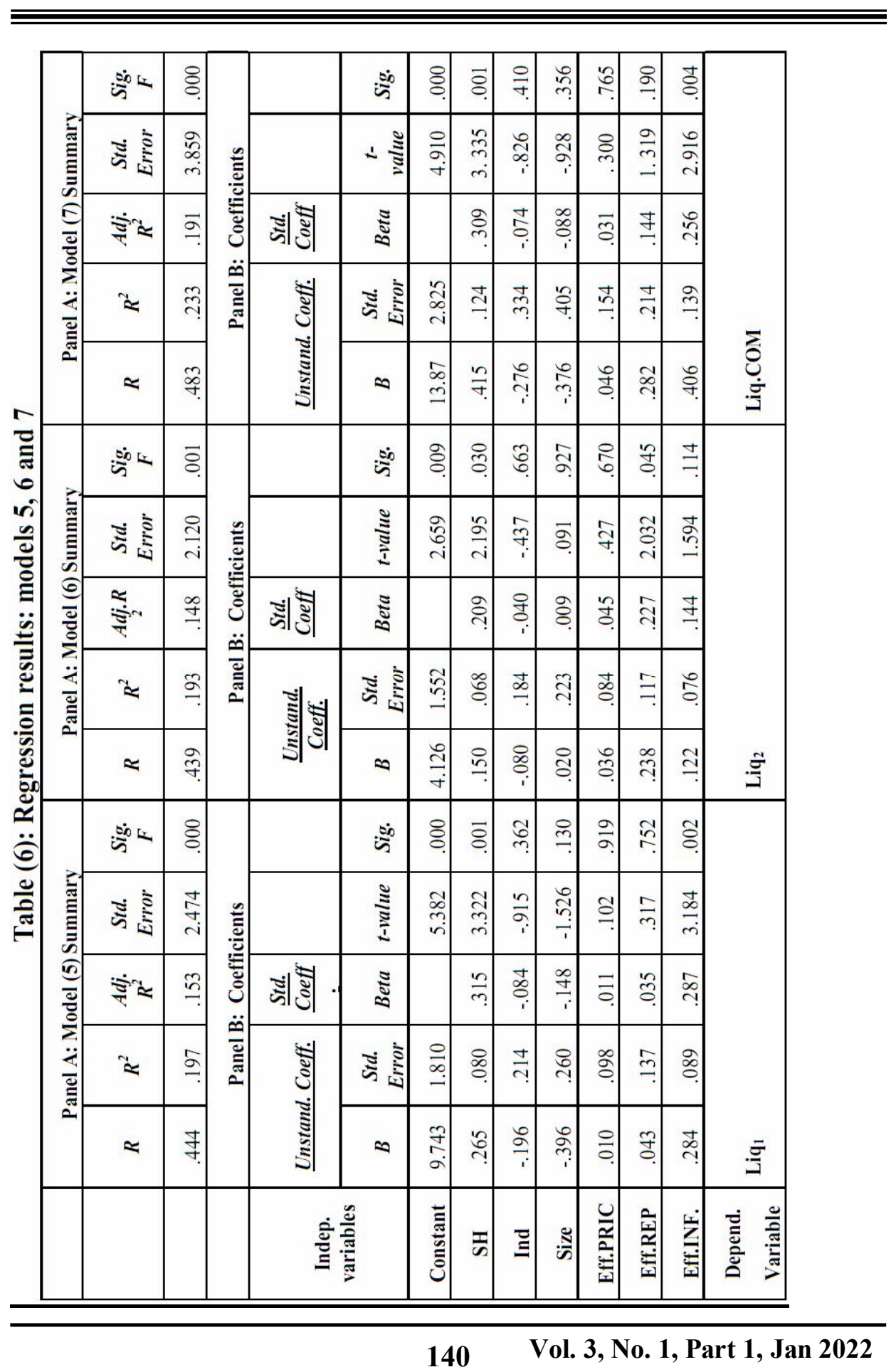


Scientific Journal for Financial and Commercial Studies and Researches

(SJFCSR) Faculty of Commerce - Damietta University

\subsubsection{Further Analvsis}

Results of the last group of questions that aimed to validate the results show that only $57.3 \%$ of respondents disagreed that short-selling would result in a less efficient stock exchange market, whereas $70.9 \%$ of respondents disagreed that short-selling would decrease the overall market liquidity. This might be attributed to asking about the effect on the overall efficiency and liquidity without specifying the measures, while the statistical analysis revealed that liquidity measures were more significant than efficiency measures to short-selling.

After testing the main study hypotheses, the researchers conducted also further analysis to test the inverse relation (i.e. the effect of market efficiency and liquidity on the activation of short-selling in Egypt). Table (7) shows that $24.4 \%$ of the activation of short-selling might be attributed to market efficiency and liquidity, besides the control variables (industry type and company size). Results show a positive significant relationship between short-selling and the compound measure of liquidity, at 0.01 . on the other hand, there is an insignificant relationship between short-selling and the compound measure of efficiency. Besides, the size of the company significantly affects the activation of short-selling at 0.05 . Supporting the assumption that if short-selling is within larger companies then market participants would be motivated to activate it. This result confirms the results of the main hypotheses, that, regardless of the direction, the relationship between short-selling and liquidity is significant, whereas that between short-selling and efficiency is insignificant.

$\mathrm{SH}=\mathrm{B}_{0}+\mathrm{B}_{1}$ Liq.COM $+\mathrm{B}_{2}$ EFF.COM $+\mathrm{B}_{3}$ Ind $+\mathrm{B}_{4}$ Size.. Model (8)

Where:

All variables: same as previous models. 
Mennah Mortada Mahfouz \& Nesma Ahmed EIShayeb

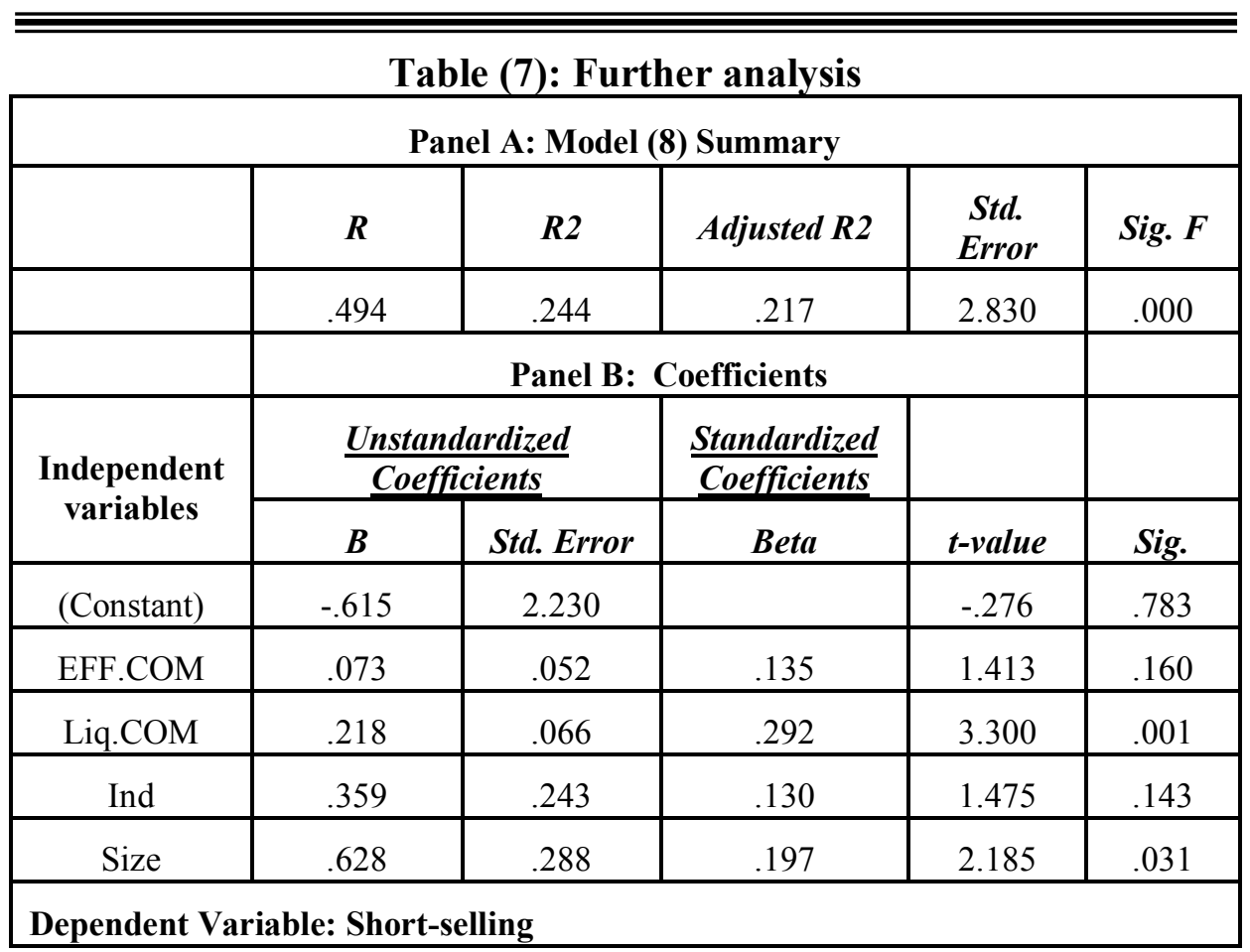

\subsection{Observations and Analysis of respondents' comments}

Practitioners are more familiar with the idea of short-selling more than academics. Some of them were so helpful and supported the topic and they were eager to get a copy of the findings. Those specialized in finance had more details regarding short-selling than other specializations. The last part of the questionnaire was an open question; asking respondents to add any relevant comment. It was mentioned that short-selling would be effective in the global depository receipt (GDR) market, and it needs more efficient markets to deal through. Moreover, it was indicated that "the above assumes professional implementation of short-selling without any difficulties from regulatory authorities". Further, another respondent viewed that although short-selling has benefits as well as limitations, it is considered a complementary instrument that might enhance the market efficiency as well as the trading volume in different directions.

In addition, it was claimed that the presence of short-selling would create equilibrium in the Egyptian stock market by imposing a new 
Scientific Journal for Financial and Commercial Studies and Researches

(SJFCSR) Faculty of Commerce - Damietta University

direction in trading, not just buying, and selling of stocks. The final comment was that short-selling would make the market less volatile. Moreover, investors would need from one to two years to understand this instrument and its effect to be able to use it. The obstacle in implementation is that most large brokerage firms face in the market nowadays, is the absence of short-sellers.

\section{Conclusion}

The objective of this paper is to examine the efficacy of the recent initiative to activate the short-selling mechanism in the Egyptian stock exchange market through the issuance of the regulatory decision no. (268) of 2019 on short-selling rules. The short-selling mechanism has been used in various stock exchange markets around the world for decades. However, many developing countries, like Egypt, were restricting the use of such a mechanism either due to lack of sufficient regulations to ensure proper application, or fear from the drawbacks that such mechanism could bring to the market. A sample of 117 questionnaires was distributed among various market participants and academics, with accounting or finance specialization, to explore their perceptions.

First, descriptive statistics and cross-tabulation show that $75 \%$ of the academic staff agreed that the consequences of short-selling would differ from developed to developing countries. Besides, $63 \%$ of financial analysts have the same opinion, compared to only $59 \%$ of brokers and $58 \%$ of other respondents. This would be justified on the ground of the lack of awareness of such a mechanism and the lack of a strict legal framework to avoid any misconduct in developing countries.

Consequently, results of multiple regression show that, overall, short-selling would not improve market efficiency where price discovery and informativeness show an insignificant relationship with short-selling, whereas financial reporting quality showed a significant positive relationship. This result indicates that short-selling would enhance the quality of financial reporting, which might reflect management's desire to correctly present financial information to attract short-sellers and avoid the negative views regarding the short companies' financial position. On the other hand, activating short-selling would not improve price 


\section{Mennah Mortada Mahfouz \& Nesma Ahmed EIShayeb}

discovery or informativeness. This could be attributed to the respondents' perception that market efficiency in developing countries with emerging economies would not be improved through one mechanism. However, it might be affected by the legal and economic environment.

Regarding the impact of short-selling activation on market liquidity, statistical analysis shows a significant positive relationship between short-selling and market liquidity, measured through trading activity and volume, bid and ask, turnover ratio, and reduced market volatility. Further, the relation between short-selling and a compound measure of liquidity indicates a significant positive relationship. Hence, most respondents support that such a mechanism would attract new investors, increase trading when the market index is declining, which, in turn, would enhance market liquidity even in an emerging market, like Egypt. Generally, academics are more optimistic than practitioners, however, the variation is only on the degree of support to our hypotheses.

The regression models considered industry type and company size as control variables. Only the size shows a significant relationship with the compound measure of efficiency as well as the price discovery and financial reporting quality. Besides, as various measures of liquidity are likely related to efficiency measures as if the market becomes more active that would lead to enhancing the efficiency gradually. Results show that informativeness affects liquidity measured by trading activity and volume and vice versa. Moreover, financial reporting quality affects liquidity measured by bid and ask, turnover ratio and volatility, and vice versa. These results mean if the market is informative and the financial reporting with high quality, then the liquidity would increase. Consequently, the traditional assumption that an efficient market would enhance liquidity, and vice versa, is also expected by market participants in Egypt as a developing country.

Finally, the further analysis examines the inverse direction of the assumed relation to investigate whether respondents regard market efficiency and liquidity would affect the activation of short-selling. Results reveal that liquidity would affect, whereas efficiency would not. These results indicate that if the market is more efficient then such a mechanism would not be necessary, while even if the market is liquid it 
Scientific Journal for Financial and Commercial Studies and Researches

(SJFCSR) Faculty of Commerce - Damietta University

is assumed that short-selling would be needed to ensure greater liquidity in such markets.

Nevertheless, the main current barrier to the application of such a mechanism in the Egyptian stock exchange market is the time needed to understand. Further, the current obstacle that most brokerage firms face nowadays is the absence of short-sellers. Moreover, as developed countries impose restrictions on short-selling in case of market instability, $64 \%$ of our respondents agree to impose restrictions in case of market instability. Finally, there is a need to increase awareness of all market participants about short-selling, its benefits, limitations, and possible effects.

\section{Future research}

After a few years, when short-selling would be more popular and more exercised within the Egyptian stock market, the variables of the study could be empirically tested; to examine the effect of short-selling on liquidity and market efficiency. These studies would apply more advanced statistical analyses. Moreover, cross-sectional studies might investigate the variations of the effect of short-selling in different industries. This effect would also be examined in small versus medium and large companies. In addition to this, interviews might be conducted with decision-makers; to get the other point of view. Furthermore, time series analysis would be made; to examine the effect of short-selling in earlier years of lifting the restrictions compared to later years. Besides, comparative studies would consider other emerging markets besides Egypt. 
Mennah Mortada Mahfouz \& Nesma Ahmed ElShayeb

\section{References}

Alves, C., Mendes, V. and da Silva, P.P., 2016. Analysis of market quality before and during short-selling bans. Research in International Business and Finance, 37, pp.252-268.

Baklaci, H.F., Suer, O. and Yelkenci, T., 2016. A closer insight into the causality between short-selling trades and volatility. Finance Research Letters, 17, pp.48-54.

Bansal, N., McKeon, R., Svetina, M. 2013. Short $\square$ sale constraints and securities lending by exchange $\square$ traded funds. Managerial Finance, 39(5), pp.444-456.

Beber, A. and Pagano, M., 2013. Short $\square$ selling bans around the world: Evidence from the 2007-09 crisis. The Journal of Finance, 68(1), pp.343-381.

Bernal, O., Herinckx, A. and Szafarz, A., 2014. Which short-selling regulation is the least damaging to market efficiency? Evidence from Europe. International Review of Law and Economics, 37, pp.244-256.

Blau, B.M. and Whitby, R.J., 2018. How does short-selling affect liquidity in financial markets?. Finance Research Letters, 25, pp.244-250.

Boehmer, E. and $\mathrm{Wu}$, J., 2013. Short-selling and the price discovery process. The Review of Financial Studies, 26(2), pp.287-322.

Boehmer, E., Jones, C.M. and Zhang, X., 2013. Shackling short-sellers: The 2008 shorting ban. The Review of Financial Studies, 26(6), pp.1363-1400.

Bris, A., Goetzmann, W.N. and Zhu, N., 2007. Efficiency and the bear: Short sales and markets around the world. The Journal of Finance, 62(3), pp.1029-1079.

Brunnermeier, M.K. and Pedersen, L.H., 2005. Predatory trading. The Journal of Finance, 60(4), pp.1825-1863. 
Scientific Journal for Financial and Commercial Studies and Researches (SJFCSR) Faculty of Commerce - Damietta University

Chague, F., De-Losso, R. and Giovannetti, B., 2019. The short-selling skill of institutions and individuals. Journal of Banking \& Finance, 101, pp.77-91.

Chang, E.C., Cheng, J.W. and Yu, Y., 2007. Short $\square$ sales constraints and price discovery: Evidence from the Hong Kong market. The Journal of Finance, 62(5), pp.2097-2121.

Chang, E.C., Lin, T.C. and Ma, X., 2019. Does short-selling threat discipline managers in mergers and acquisitions decisions? Journal of Accounting and Economics, 68(1), p.101-223.

Chang, E.C., Luo, Y. and Ren, J., 2014. Short-selling, margin-trading, and price efficiency: Evidence from the Chinese market. Journal of Banking \& Finance, 48, pp.411-424.

Chen, H., Chen, Y., Lin, B. and Wang, Y., 2019. Can short-selling improve internal control? An empirical study based on the difference $\square$ in $\square$ differences model. Accounting \& Finance, 58(5), pp.1233-1259.

Chen, J., Kadapakkam, P.R. and Yang, T., 2016. Short-selling, margin trading, and the incorporation of new information into prices. International Review of Financial Analysis, 44, pp.1-17.

Christophe, S.E., Ferri, M.G. and Hsieh, J., 2010. Informed trading before analyst downgrades: Evidence from short-sellers. Journal of Financial Economics, 95(1), pp.85-106.

Dechow, P.M., Hutton, A.P., Meulbroek, L. and Sloan, R.G., 2001. Short-sellers, fundamental analysis, and stock returns. Journal of Financial Economics, 61(1), pp.77-106.

Desai, H., Krishnamurthy, S. and Venkataraman, K., 2006. Do shortsellers target firms with poor earnings quality? Evidence from earnings restatements. Review of Accounting Studies, 11(1), pp.71-90.

Deshmukh, S., Gamble, K.J. and Howe, K.M., 2015. Short-selling and firm operating performance. Financial Management, 44(1), pp.217-236. 
Mennah Mortada Mahfouz \& Nesma Ahmed ElShayeb

Diamond, D.W. and Verrecchia, R.E., 1987. Constraints on short-selling and asset price adjustment to private information. Journal of Financial Economics, 18(2), pp.277-311.

Diether, K.B., Lee, K.H. and Werner, I.M., 2009. Short-sale strategies and return predictability. The Review of Financial Studies, 22(2), pp.575-607.

Ebrahimnejad, A. and Hoseinzade, S., 2019. Short-sale constraints and stock price informativeness. Global Finance Journal, 40, pp.2834.

Engelberg, J.E., Reed, A.V. and Ringgenberg, M.C., 2018. Short $\square$ selling risk. The Journal of Finance, 73(2), pp.755-786.

Financial Regulatory Authority web site http://www.fra.gov.eg/content/efsa_en/efsa_news_en/efsa_750_e n.htm, accessed on July 92019.

Gao, Y. and Gao, Y., 2015. Statistical properties of short-selling and margin-trading activities and their impacts on returns in the Chinese stock markets. Physica A: Statistical Mechanics and its Applications, 438, pp.293-307.

Gehy, D., 2013. Three Essays on the Role of Short-sellers in the Financial Markets. A Dissertation submitted to the Department of Finance in partial fulfillment of the requirements for the degree of Doctor of Philosophy. THE FLORIDA STATE UNIVERSITY COLLEGE OF BUSINESS.

Geracia, M.V., Garbaravi ciusb, T. and Veredasc, D., 2018. Shortselling in extreme events. Journal of Financial Stability, 39, pp. 90-103.

Hair, J., Black, W., Babin, B. and Anderson, R., 2010. Multivariate data analysis $7^{\text {th }}$ edth ed.

Hu, T. and Chi, Y., 2019. Can short-selling activity predict the future returns of non-shortable peer firms?. Pacific-Basin Finance Journal, 53(C), pp.165-185. 
Scientific Journal for Financial and Commercial Studies and Researches (SJFCSR) Faculty of Commerce - Damietta University

Jain, A., Jain, P.K., McInish, T.H. and McKenzie, M., 2013. Worldwide reach of short-selling regulations. Journal of Financial Economics, 109(1), pp.177-197.

Jiang, H. and Chen, J., 2019. Short-selling and financial reporting quality: Evidence from Chinese $\mathrm{AH}$ shares. Journal of Contemporary Accounting \& Economics, 15(1), pp.118-130.

Jiang, L. and Pang, L., 2016. Does short-selling enhance the allocational role of stock price? Evidence from Hong Kong. Journal of International Financial Management \& Accounting, 27(3), pp.269-297.

Jin, Z., Lin, B., Yang, X. and Zhang, T., 2018. Accounting conservatism and short-selling: Evidence from China. Journal of Business Finance \& Accounting, 45(3-4), pp.352-394.

Jones, C.M. and Lamont, O.A., 2002. Short-sale constraints and stock returns. Journal of Financial Economics, 66(2-3), pp.207-239.

Karpoff, J.M. and Lou, X., 2010. Short-sellers and financial misconduct. The Journal of Finance, 65(5), pp.1879-1913.

Lensberg, T., Schenk-Hoppé, K.R. and Ladley, D., 2015. Costs and benefits of financial regulation: Short-selling bans and transaction taxes. Journal of Banking \& Finance, 51, pp.103-118.

Lepone, A., Wen, J., Wong, J.B. and Yang, J.Y., 2019. Short-selling restrictions and index futures pricing: Evidence from China. International Review of Economics \& Finance, 61, pp.179-187.

Lou, X., 2007. Short-sellers and Financial Misrepresentation. ProQuest. A dissertation submitted in partial fulfillment of the requirements for the degree of Doctor of Philosophy University of Washington.

M Weiner, P., Totino, E. and D Weber, R., 2004. Short sales: New rules and recent enforcement actions. Journal of Investment Compliance, 5(3), pp.9-14.

McKenzie, M. and Henry, Ó.T., 2012. The determinants of short-selling: evidence from the Hong Kong equity market. Accounting \& Finance, 52, pp.183-216. 
Mennah Mortada Mahfouz \& Nesma Ahmed ElShayeb

Mertzanis, C., 2017. Short-selling regulation, return volatility and market volatility in the Athens Exchange. Studies in Economics and Finance, 34(1), pp.82-104.

Miller, E.M., 1977. Risk, uncertainty, and divergence of opinion. The Journal of Finance, 32(4), pp.1151-1168.

Saffi, P.A. and Sigurdsson, K., 2011. Price efficiency and short-selling. The Review of Financial Studies, 24(3), pp.821-852.

Sharif, S., Anderson, H.D. and Marshall, B.R., 2014. The announcement and implementation reaction to China's margin trading and shortselling pilot programme. International Journal of Managerial Finance, 10(3), pp.368-384.

Sobaci, C., Sensoy, A. and Erturk, M., 2014. Impact of short-selling activity on market dynamics: Evidence from an emerging market. Journal of Financial Stability, 15, pp.53-62. 
Scientific Journal for Financial and Commercial Studies and Researches

(SJFCSR) Faculty of Commerce - Damietta University

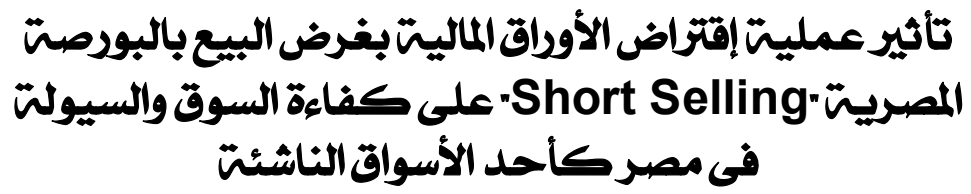

د. منل مرتضى محفوظ، د. نسمل أحمد الشايب

المستشخلص:

تهذف هذه الدراسة إلى مناقثة المبادرة الأخيرة لتفعيل آلية عملية إقتراض الأوراق

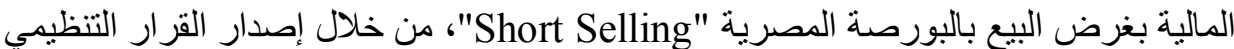

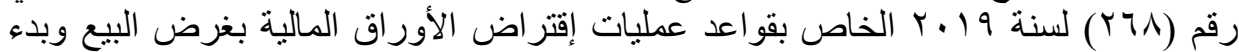

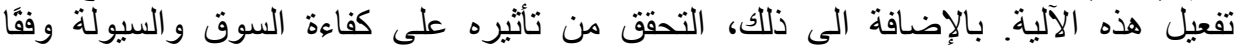

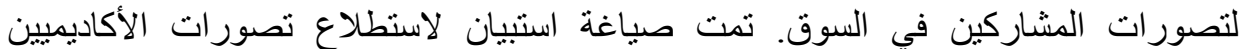

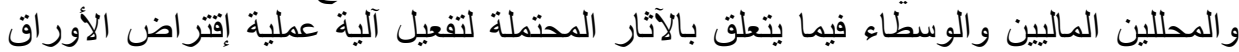

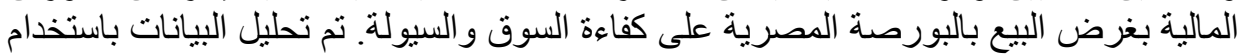

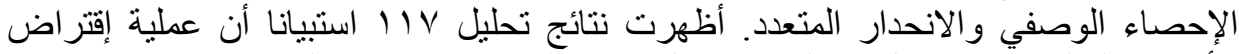

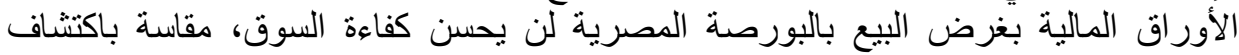

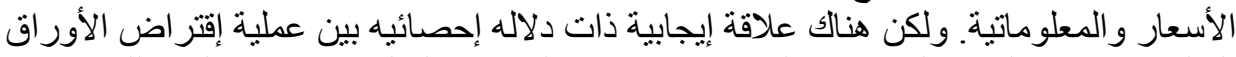

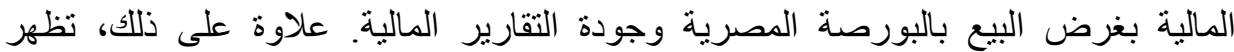

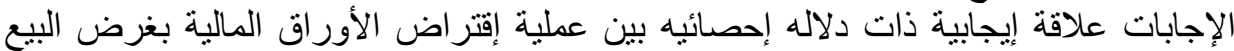

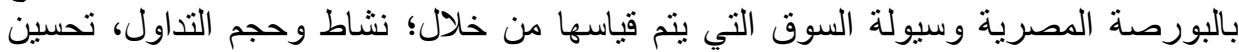

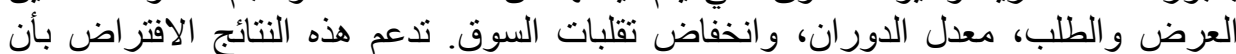

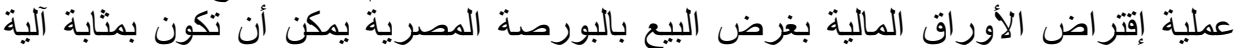

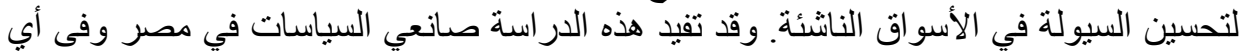

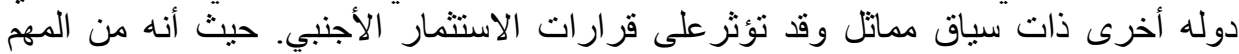

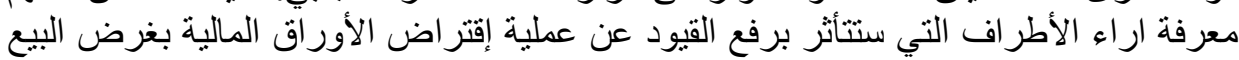

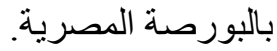

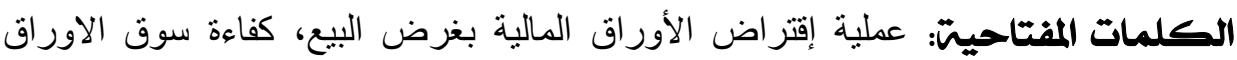

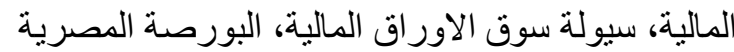

